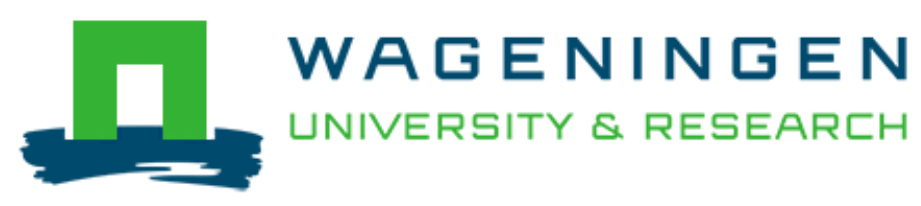

\title{
Do field-level practices of Cambodian farmers prompt a pesticide lock-in?
}

Flor, R. J., Maat, H., Hadi, B. A. R., Kumar, V., \& Castilla, N.

This is a "Post-Print" accepted manuscript, which has been published in "Field Crops Research"

This version is distributed under a non-commercial no derivatives Creative Commons (c) (1) $\Theta \Theta$

(CC-BY-NC-ND) user license, which permits use, distribution, and reproduction in any medium, provided the original work is properly cited and not used for commercial purposes. Further, the restriction applies that if you remix, transform, or build upon the material, you may not distribute the modified material.

Please cite this publication as follows:

Flor, R. J., Maat, H., Hadi, B. A. R., Kumar, V., \& Castilla, N. (2019). Do field-level practices of Cambodian farmers prompt a pesticide lock-in? Field Crops Research, 235, 68-78. DOI: $10.1016 /$ j.fcr.2019.02.019

You can download the published version at:

https://doi.org/10.1016/j.fcr.2019.02.019 
Do field-level practices of Cambodian farmers prompt a pesticide lock-in?

4

5

6

7

8

Rica Joy Flor ${ }^{1,2}$, Harro Maat ${ }^{1}$, Buyung Asmara Ratna Hadi $^{2}$,

Virender $\mathrm{Kumar}^{3}$ and Nancy Castilla ${ }^{3}$

${ }^{1}$ Knowledge Technology and Innovation Group, Department of Social Sciences, Wageningen University and Research, 6706 KN Wageningen, Netherlands 2 Sustainable Impact Platform, International Rice Research Institute, IRRI-Cambodia Office, 12101 Phnom Penh, Cambodia

${ }^{3}$ Sustainable Impact Platform, International Rice Research Institute, DAPO Box 777, Manila,

Philippines 
Do field-level practices of Cambodian farmers prompt a pesticide lock-in?

\begin{abstract}
Agronomic practices such as fertilizer application or seed rates have been known to affect rice pests and damage, but the evidence is often blurred in studies on pest management decisions and invisible in studies on pesticide lock-in. Combined agronomic practices and pesticide use may create technological lock-in, occurring when the combination has accumulated advantages over time which encourages its continued use, even if better options are available. We present results from a survey among farmers $(\mathrm{N}=400)$ from five provinces in Cambodia. We asked about field-level, agronomic practices and applied a regression analysis to determine whether these practices affect pesticide application. Farmers from the selected provinces produce rice intensively, particularly those in provinces in the Mekong Delta where a percentage of farmers would aim for three crops per year.

Cambodian farmers in the five sampled provinces rely on pesticides for pest control with an average of 2-5 applications each for herbicide and insecticide, and 1-6 applications of fungicide per season. Farmers from the Mekong Delta, particularly Prey Veng Province, made more pesticide applications. Interestingly, of nine agronomic practices tested, six were found to significantly correlate with no applications as in organic management recommendations, as well as misuse of pesticides. Varied combinations of agronomic practices including seed rate, crop establishment method, seed treatment, cultivating larger landholdings, irrigation through gravity irrigation system, and number of fertilizer applications predicted herbicide, insecticide and fungicide application. Interactions varied across wet and dry season. Pesticide use makes sense to farmers given a specific combination of agronomic practices. Therefore we argue that field-level agronomic practices contribute to pesticide lock-in as much as wider innovation system conditions such as trade and regulation of pesticides.

These findings imply that addressing the pesticide lock-in to facilitate a shift to more sustainable practices, such as Integrated Pest Management, should not only aim at broader innovation systems or industry level changes. There are adjustments and fine-tuning of agronomic practices that also need to be made to wean farmers from pesticide reliance.
\end{abstract}

Key words: agronomic practices; pesticide lock-in; sustainability; Cambodia; Mekong Delta 


\section{Introduction}

There are important relationships between agronomic practices and pest management for rice. Agronomic practices, such as planting synchrony or fertilizer application, affect pest intensity and damage (e.g. Reddy et al. 1979, Holt and Chancellor 1997, Thien et al. 1999, Htwe et al. 2013). Studies on decisions for pest management, however, often fail to clarify the effects of such field-level interactions and how they are connected to farm operations. Moreover, analysis of pest management practices often highlight causes external to the field; such as demographic characteristics (Matsukawa et al. 2016), beliefs (Heong and Escalada 1999), knowledge gaps relating to extension (Heong 1999), pesticide availability and associated regulations (Parveen and Nakagoshi 2001), or costs and benefits of pest management choice (Mumford and Norton 1984). These factors are indeed at play and are important. However, without addressing operational practices of farmers, it remains unclear how such external factors interact with field-level pesticide management. Of particular interest are the practices of farmers in the Mekong Delta, where farmers produce rice intensively in a vulnerable wetland ecosystem.

A particular strand of literature considers pest management to be affected by technological lock-in. Originally, the idea of technological lock-in emerged from the economics of technology adoption. This literature defines lock-in as the use of incumbent tools and practices (technologies) that accumulate economic and cultural advantages, making the shift to alternative technologies difficult or costly (Arthur 1989, Perkins 2003). As the technology is adopted and spread, in this case pesticides, the technique co-evolves with socio-economic conditions that created accumulated advantages and thereby a lock-in (Cowan and Gunby 1996, Foxon 2013). This lock-in is a stable social and technical configuration where the technology is linked to, for example, existing policies and distribution networks, together creating incentives for use that an alternative technology would not have. Furthermore, pesticide lock-in has been found inherent in the innovation system, affected by factors such as markets, regulations, and extension services (Vanloqueren and Baret 2007). Lock-in is also found to be induced by the economic decisions of the farmer because of gender, education, sources of information, and crops cultivated (Wagner et al. 2016). Another factor contributing to lock-in is the way in which the chemical industry produces and markets pesticides (Joly and Lemarie 2002). A field-level study by Spangenberg et al. (2015) attributes lock-in effects to the specific pest management response of farmers towards pest pressures, in particular insecticide use triggering more insecticide use than necessary. While these forces may indeed be at play, the effect of interrelated agronomic practices at field level on pest management practices remains overlooked. Little is known about how the aggregate of agronomic practices for rice cultivation such as fertilizer use, seed rates, or rice varieties contributes to the way farmers decide to use pesticides.

The aim of this paper is to examine whether field-level agronomic practices, i.e. different operations by which farmers manage their crop, affect pesticide use. By examining field operations of Cambodian rice farmers, we aim to develop insights on what these field-level agronomic practices could mean for the debate on pesticide lock-in. 


\subsection{Agronomic practices that create conducive conditions for pests}

For this study, we hypothesize that agronomic practices, defined as particular sets of field operations, affect the pesticide use of farmers. This hypothesis is based on field studies looking into agronomic practices that affect pest populations and crop damage.

One important field operation is the application of synthetic fertilizer. Nitrogen in particular has a direct effect on the intensity of diseases and pest injuries by affecting the plant anatomy and physiology. Nitrogen increases the susceptibility of the plant by reducing cellulose and lignin, which provide mechanical barrier against pathogens and insect pests (Koyama 1955, Matsuyama 1975, Huber et al. 2012). Nitrogen also reduces the amount of phenols (Kiraly 1964, Matsuyama and Dimond 1973), which are among the defensive substances in plant cell walls that inhibit the survival of pathogens and sap feeders, such as green leafhoppers and brown planthoppers (Vaithilingam and Baskaran 1985). Another effect of excess amount of nitrogen is a prolonged vegetative stage of the crop (Vergara et al., 1964) which increases the infectious period of foliar diseases and favors insect pests that normally attack young tissues. High nitrogen increases the fitness and consequent population of planthoppers ( $\mathrm{Lu}$ et al. 2004, $\mathrm{Lu}$ and Heong 2009).

Another field operation is crop establishment, which implicates seeding rate or plant spacing. High rice plant density through higher seeding rate or closer spacing in transplanting is used for weed suppression (Ahmed et al. 2014; Chauhan et al. 2011) but a likely effect is that it increases the intensity of diseases and insect pest injuries. High nitrogen and seeding rates create a closed canopy and dense plant structure that extends leaf wetness duration and promotes a favorable microclimate for pathogens and insect pests (Savary and Castilla, 2013). These conditions also reduce the search efficiency of natural enemies of insect pests (De Kraker et al., 2000).

Variety choice is an important factor for crop diseases. Obviously, varieties without resistance are more vulnerable (Heinrichs et al. 2017). The use of resistant varieties affects insect populations and their damage to the rice crop (Cohen et al. 1997, Alam and Cohen 2003). Also water management and planting date affects populations of rice pests such as water weevil and stink bugs (Albuquerque 1993, Stout et al. 2002). Yet another factor is planting synchrony. Asynchronous planting is reported to increase the population of insect pests (Loevinsohn et al. 1993) and to increase the incidence of tungro disease (Holt and Chancellor 1997, Cabunagan et al. 2001) because it allows continued host availability. In the same way, it affects rodent populations because breeding of rodents continue as long as there are rice crops (Htwe et al. 2013).

Additionally, many weed related issues have emerged where scarce and expensive labor conditions have caused a shift in crop establishment methods from conventional puddled transplanted rice (PTR) to direct seeding of rice (DSR). Greater weed infestation results in higher risk of yield losses and consequently leads to increased use of herbicides for weed control in DSR (Pandey and Velasco 2002, Ikeda et al. 2008, Martin et al. 2017). The shift from PTR to DSR also increases the intensity of some insect pests and diseases, such as brown planthopper and brown spot (Savary et al. 2005). 
In this paper we focus on particular agronomic practices, which are known to affect pest incidence or damage, and assess their effect on pest management practices. Thus, factors such as yield, profitability as well as farm characteristics were considered constant.

\section{Methods}

\subsection{Survey of farmers from five provinces}

We interviewed 80 farmers from each of the following five provinces in Cambodia: Battambang, Kampong Thom, Prey Veng, Takeo and Pursat to understand their current crop management practices. These sites represent intensive lowland rice production areas in the country (Figure 1), specifically Prey Veng and Takeo which are in the Mekong Delta. These delta provinces are of particular interest for pest management because farmers here have greater access to irrigation water and can produce more rice crops per year.

Two villages from each province were selected for the survey. The villages were selected for having intensively cultivated rice areas (at least two rice crops per year), access to irrigation, short distance to a research station where extension advice is available, and accessibility by road. Although similar for all provinces, the three other provinces that are not in the Mekong Delta have different ecological conditions owing to their proximity to the Tonle Sap Lake and differing access to irrigation. The two villages are located in different districts of each province. From a list of farmers in each village, we randomly sampled 40 for interviews in late 2016. Questions were on the characteristics of the farms and crop management practices ranging from land preparation to harvest. The emphasis of the survey was to understand the pest management and input use of farmers during the wet and dry seasons of 2015 to 2016 . One limitation in this survey method was that many farmers could not recall the amount of organic fertilizer (e.g. cow manure) they applied on their fields. For all respondents, organic fertilizer data was excluded in the analysis, although the total number of applications included all organic and inorganic fertilizer applications.

Informed consent was obtained from all farmers surveyed. Prior to the survey, focus group discussions and key informant interviews were done to obtain qualitative data on farming practices in the villages, and to pre-test the questionnaire. Data on pest management practices were analysed using descriptive statistics. 


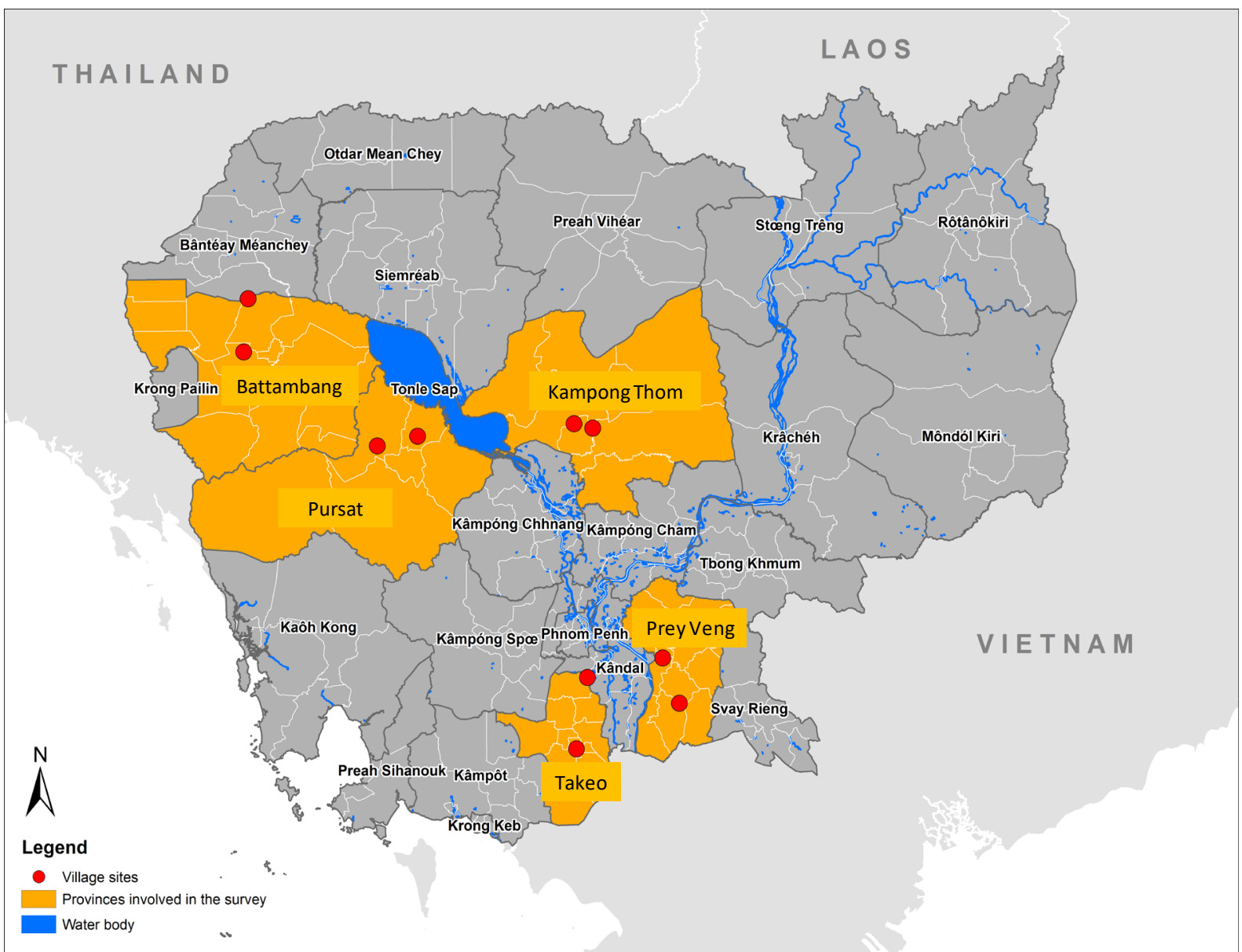

Figure 1. Map of Cambodia showing location of villages surveyed in five provinces

\subsection{Statistical analysis}

Through analysis of means, we found the most commonly practiced pest management action was the use of pesticides; and specifically herbicides, insecticides and fungicides. This concurs with results of previous studies on pesticide use in Cambodia by Matsukawa et al. (2017). We thus further analysed the agronomic practice variables that could have affected such pesticide use.

We used multinomial logistic regression (MLR) to examine which agronomic practices have an effect on categories of pesticide application. MLR takes maximum likelihood estimations to predict the probabilities of different possible outcomes of a categorical dependent variable (such as pesticide use), given a set of independent categorical, binary, or numeric variables (Tabanick et al. 2001, Madhu et al. 2014). This approach provides robust findings with easily interpretable diagnostics, without the conditional data assumptions such as multivariate normality, and equal variance and co-variance (Tabanick et al. 2001, Chan 2005).

We compared between categories, rather than actual number of applications. The categories are defined according to specific recommendations. One category is no pesticide application which is recommended for organic rice production. Another category allows for a minimal number of applications, such as those promoted by the Sustainable Rice Platform (SRP, Stuart et al. 2018). This also relates to existing recommendations if pesticides are needed (IRRI 2015, IRRI et al. 2017). These research-based recommendations provide scope for adjustment 
based on the field conditions being faced by the farmer. The third category is not recommended but represents practices where farmers misuse pesticides. We use the term misuse considering both number of application and timing of applications. In the SRP recommendations, an important consideration is also the timing of the application, e.g. 'no insecticide application in the first 40 days', 'no fungicide application after flowering stage', or 'herbicide should be applied early, before the crop canopy closes, no application after 40DAS' (SRP 2015, Stuart et al. 2018). The categorization considers that there are ideal situations where farmers would not apply any pesticide, but then there are also situations that cover a range within as well as beyond the acceptable number of applications. We defined categories for herbicide and insecticide applications as follows: Organic $=0$ applications, SRP $=1-2$, and Pesticide misuse $=3$ or more. For fungicide application: Organic $=0$ applications, $\mathrm{SRP}=1$, and Pesticide misuse $=2$ or more. In the SRP recommendation for fungicide, application is only when needed with no application after the flowering stage (Stuart et al. 2018). We used sustainable practice as the base outcome for comparative analysis between an ideal practice of not using pesticide (no application as in organic recommendations) and the practice of pesticide misuse.

For the model, we tested varied agronomic variables from practices theorized to have an effect on the intensity of pest damage. The variables used in the model were coded in Stata (Stata IC 13.1) and are described in Table 1.

Table 1. Coded variable names and definitions used for regression analysis.

\begin{tabular}{ll}
\hline Variable & Description \\
\hline Herbicide application & $\begin{array}{l}\text { Number of herbicide applications categorized }: 0=\text { recommended for organic } \\
\text { production, no applications, } 1=\mathrm{SRP} * \text { recommendation, with no more than } 2 \\
\text { applications, and } 2=\text { pesticide misuse, } \geq 3 \text { applications }\end{array}$ \\
Insecticide application & $\begin{array}{l}\text { Number of insecticide applications; } 0=\text { recommended for organic production, } \\
\text { no applications, } 1=\mathrm{SRP} * \text { recommendation, with no more than } 2 \text { applications, } \\
\text { and } 2=\text { pesticide misuse, } \geq 3 \text { applications }\end{array}$ \\
Fungicide application & $\begin{array}{l}\text { Number of fungicide applications; } 0=\text { recommended for organic production, no } \\
\text { applications, } 1=\mathrm{SRP} * \text { recommendation, no more than } 2 \text { applications with no } \\
\text { applications after flowering stage, and } 2=\text { pesticide misuse, } \geq 2 \text { applications }\end{array}$ \\
CE method & $\begin{array}{l}\text { Crop establishment method, } 0=\text { puddled transplanted rice (PTR), } 1=\text { direct } \\
\text { seeded rice (DSR) }\end{array}$ \\
Seed treatment & $\begin{array}{l}\text { Mixing the seeds with pesticides, } 0=\text { with seed treatment, } 1=\text { no seed treatment } \\
\text { Seed rate }\end{array}$ \\
Amount of seeds used per hectare (in kilograms)
\end{tabular}




\begin{tabular}{ll}
\hline N_kg ha & -1 \\
Total nitrogen in kilograms per ha applied per season, in the form of chemical \\
fertilizers
\end{tabular}

*Recommended for sustainable production through the Sustainable Rice Platform (SRP) standards, see Stuart et al. in this issue; **Identified resistant cultivars based on variety characteristics documented by Ouk et al. (2017)

Farmers' practices were significantly different across wet and dry seasons, thus a total of six separate MLR analyses were run testing the agronomic variables on herbicide, insecticide and fungicide application categories in wet and dry seasons. For each model, we first tested for multi-collinearity by running simple correlations and partial correlations among the independent variables (Mustapha et al. 2017). This test resulted in exclusion of variables in specific models where there was collinearity of the data. We also ran a simple least squares regression analysis to check all remaining independent variables for multicollinearity, through a variance inflation factor (VIF) test. The VIF with values $>10$ means that there are variables that are multicollinear. The VIF values for the six MLR analyses showed no multicollinearity among independent variables.

\section{Results}

\subsection{Farmers' current pest management practices}

The interviewed farmers are largely pesticide reliant. In the different provinces, only up to $9 \%$ of farmers adopted cultural methods, which directly target the pests and remove these through manual or mechanical means. These include hand weeding, manual picking of snails, and rat hunting (Figure 2). Most farmers applied herbicides and insecticide. Although there is considerable variation within provinces, more farmers from Prey Veng and Takeo used insecticides, while more farmers in Battambang and Prey Veng used herbicides, than those from other provinces.

A. Dry season

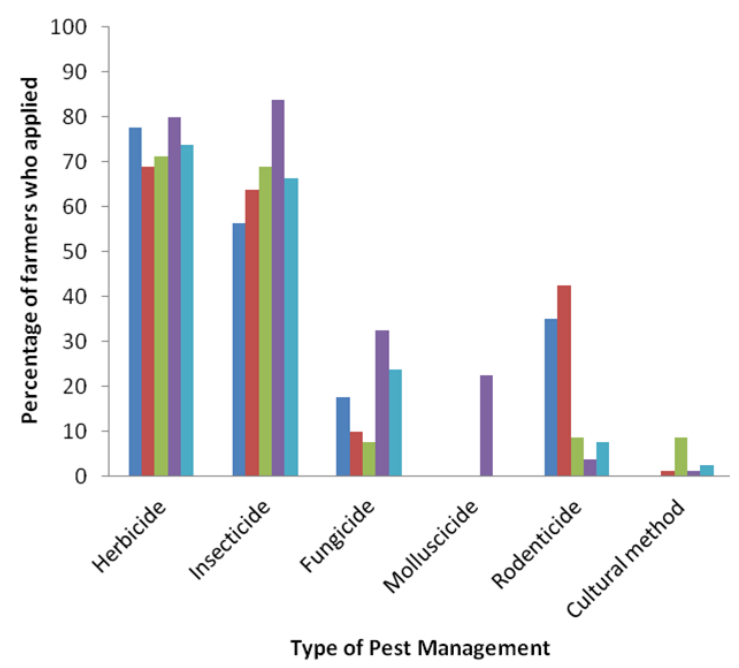

B. Wet season

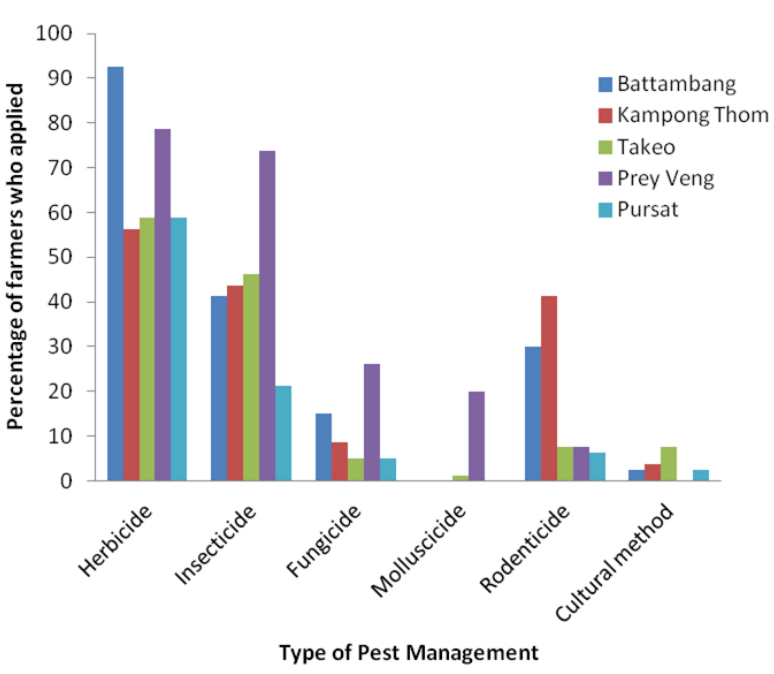


Of the farmers who applied pesticides, they averaged 2 to 5 applications of herbicide and insecticide, whereas molluscicide use was low (Table 2). The highest number of pesticide applications was observed among farmers in Prey Veng. In many cases, farmers mixed different types of pesticides (usually herbicide and insecticide) within one application. Rodenticides are used across all provinces; and while not many farmers apply rodenticides (Figure 2), some farmers made 14 applications in one season (Table 2).

Table 2. Mean number of applications with minimum and maximum applications for farmers using pesticides, and standard deviation (SD) by province, for each pesticide in the dry and wet seasons in 2015-16.

\begin{tabular}{|c|c|c|c|c|c|c|c|c|c|c|}
\hline \multirow[t]{2}{*}{ Province } & \multicolumn{2}{|c|}{$\begin{array}{l}\text { Herbicide } \\
\min , \max \end{array}$} & \multicolumn{2}{|c|}{$\begin{array}{l}\text { Insecticide } \\
\min , \max \\
\end{array}$} & \multicolumn{2}{|c|}{$\begin{array}{c}\text { Fungicide } \\
\min , \max \end{array}$} & \multicolumn{2}{|c|}{$\begin{array}{c}\text { Molluscicide } \\
\text { min, } \max \end{array}$} & \multicolumn{2}{|c|}{$\begin{array}{c}\text { Rodenticide } \\
\min , \max \end{array}$} \\
\hline & Dry & Wet & Dry & Wet & Dry & Wet & Dry & Wet & Dry & Wet \\
\hline \multirow[t]{2}{*}{ Battambang } & $3(1.6)$ & $3(0.2)$ & $4(2.0)$ & $2(0.3)$ & $4(1.4)$ & $2(0.3)$ & & & $4(1.9)$ & $2(0.1)$ \\
\hline & 1,9 & 1,9 & 1,9 & 1,11 & 2,7 & 1,4 & & & 2,9 & 1,3 \\
\hline \multirow[t]{2}{*}{$\begin{array}{l}\text { Kampong } \\
\text { Thom }\end{array}$} & $4(2.4)$ & $2(0.1)$ & $5(2.5)$ & $2(0.2)$ & $5(1.3)$ & $1(0.2)$ & & & $7(3.6)$ & $2(0.4)$ \\
\hline & 1,14 & 1,4 & 1,14 & 1,5 & 2,6 & 1,2 & & & 2,14 & 1,12 \\
\hline \multirow[t]{2}{*}{ Prey Veng } & $5(2.0)$ & $2(0.1)$ & $5(2.0)$ & $4(0.4)$ & $6(1.8)$ & $2(0.7)$ & $5(1.6)$ & $1(0.1)$ & $5(3.2)$ & $\begin{array}{c}1 \\
(0.20)\end{array}$ \\
\hline & 1,10 & 1,6 & 1,10 & 1,15 & 2,9 & 1,16 & 2,8 & 1,2 & 3,9 & 1,3 \\
\hline \multirow[t]{2}{*}{ Takeo } & $4(2.7)$ & $2(0.2)$ & $5(2.8)$ & $3(0.3)$ & $3(0.5)$ & $2(0.5)$ & & $1(0)$ & $8(3.1)$ & $2(0.3)$ \\
\hline & 1,11 & 1,7 & 1,11 & 1,7 & 3,4 & 1,3 & & 1,1 & 2,11 & 1,3 \\
\hline \multirow[t]{2}{*}{ Pursat } & $3(1.3)$ & $2(0.1)$ & $4(1.6)$ & $2(0.3)$ & $5(1.5)$ & $1(0.2)$ & & & $4(1.6)$ & $1(0.2)$ \\
\hline & 1,7 & 1,6 & 2,8 & 1,5 & 3,8 & 1,2 & & & 1,6 & 1,2 \\
\hline
\end{tabular}

*Value in parentheses is standard deviation; Wet season data published in Flor et al. 2018

\subsection{Agronomic practices of Cambodian farmers}

Most farmers established their rice crop through broadcast DSR. Of the farmers surveyed, $87 \%$ established their crop through broadcast DSR in the wet season, and it increased to $99 \%$ in the dry season. Farmers in Cambodia used high seed rates ranging from $175 \mathrm{~kg} \mathrm{ha}^{-1}$ in Pursat to $327 \mathrm{~kg} \mathrm{ha}^{-1}$ in Prey Veng in the dry season (Fig. 3a). In the wet season, seed rates ranged from $150 \mathrm{~kg} \mathrm{ha}^{-1}$ in Battambang and Pursat to $313 \mathrm{~kg} \mathrm{ha}^{-1}$ in Prey Veng (Fig. 3b). Among surveyed farmers, only $3 \%$ applied seed treatments prior to sowing. 

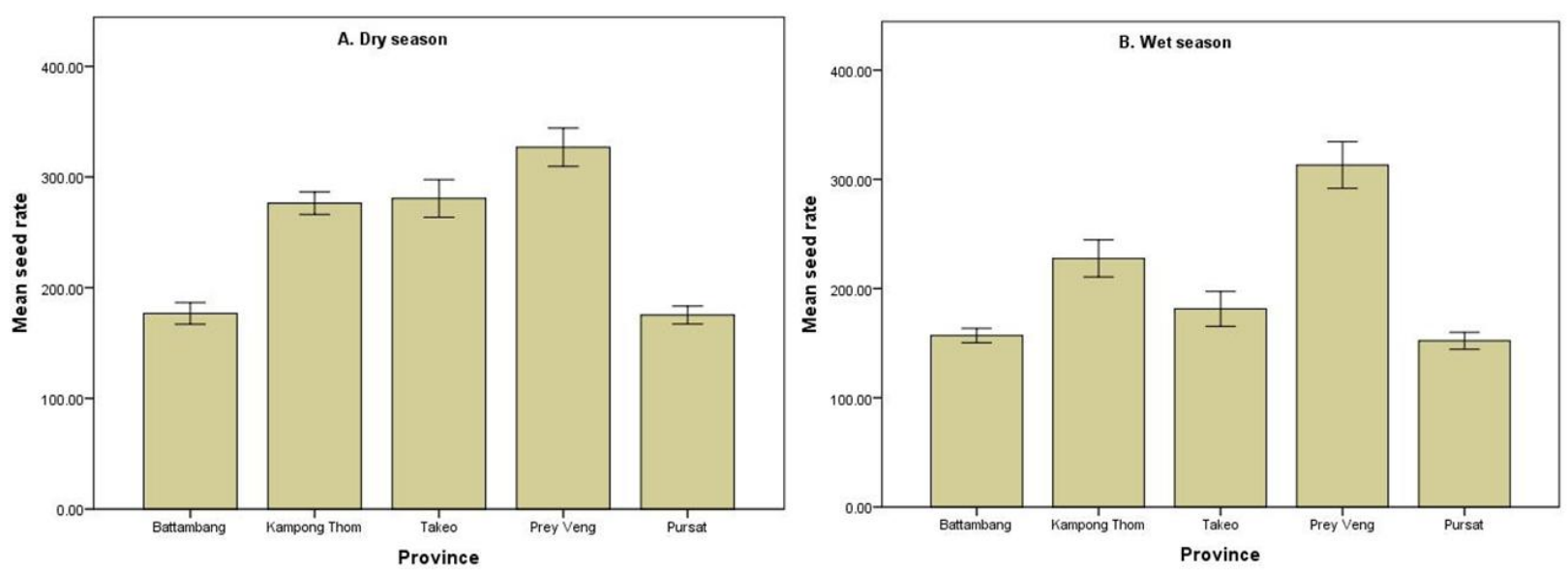

Figure 3. Seed rate (kg ha-1) used by Cambodian farmers in the a) dry and b) wet seasons 201516 by province; Error bars: +/-2 SE

Among the preferred varieties in the wet season were long-duration and photoperiod-sensitive varieties, such as Phka Rumduol, Phka Kgney, and Riang Chey (Table 3). These are traditional varieties sourced by farmers and exchanged between farmers rather than through certified seed producers. Of the farmers surveyed, $69 \%$ used farmers' saved seeds, $8 \%$ exchanged from other farmers, and only $8 \%$ used certified seeds. There were short duration varieties, such as Sen Kra Oub and IR66, that were also grown in the dry season.

In the dry season, farmers in most provinces planted IR50404 and OM4900, which are short duration varieties. These two varieties were introduced through informal exchanges with neighbouring Vietnam. The seeds for the dry season crop were mostly sourced from saved seeds of the farmers $(65 \%)$, exchanged from other farmers $(11 \%)$ and certified seeds $(5 \%)$.

Table 3. Top three varieties planted by farmers in each province, dry and wet season 2015-16

\begin{tabular}{|l|l|l|l|l|l|}
\hline Season & Battambang & Kampong Thom & Takeo & Prey Veng & Pursat \\
\hline \multirow{3}{*}{ Dry } & Sen Kra Oub & IR50404* & IR50404* & IR50404* & Sen Kra Oub \\
\cline { 2 - 6 } & Srov Sro Nge & OM4900** & IR66 & IR66 & Phka Malis \\
\cline { 2 - 6 } & IR50404* & & OM4900** & & Somaly \\
\hline \multirow{3}{*}{ Wet } & Sen Kra Oub & OM4900** & Phka Kgney & IR50404* & Somaly \\
\cline { 2 - 6 } & Phka Rumduol & IR50404* & IR50404* & Phka Rumduol & Phka Rumduol \\
\cline { 2 - 6 } & Neang Khon & Phka Rumduol & Phka Rumduol & IR66 & Riang Chey \\
\hline
\end{tabular}

*Locally, IR50404 is also known as ‘504', and ** OM 4900 is also ‘4900' or '4900 Kro Mom Yourn’

Within and between villages, farmers used different sources of irrigation water. About $76 \%$ of the farmers surveyed depend on their own pumps, and $11 \%$ of the farmers are part of a gravity irrigation system. The latter typically results in synchronous planting. An examination of their planting dates (coded by week) per village indicated a broad spread of planting dates across the year (Figure 4). In some villages such as Thom and Sdao in Prey Veng, farmers started their cropping season at various times throughout the year, and there is no clear fallow period. 
In comparison, for O Kunthor Tbong in Kampong Thom, where more farmers rely on the gravity irrigation system, farmers planted within the same period.

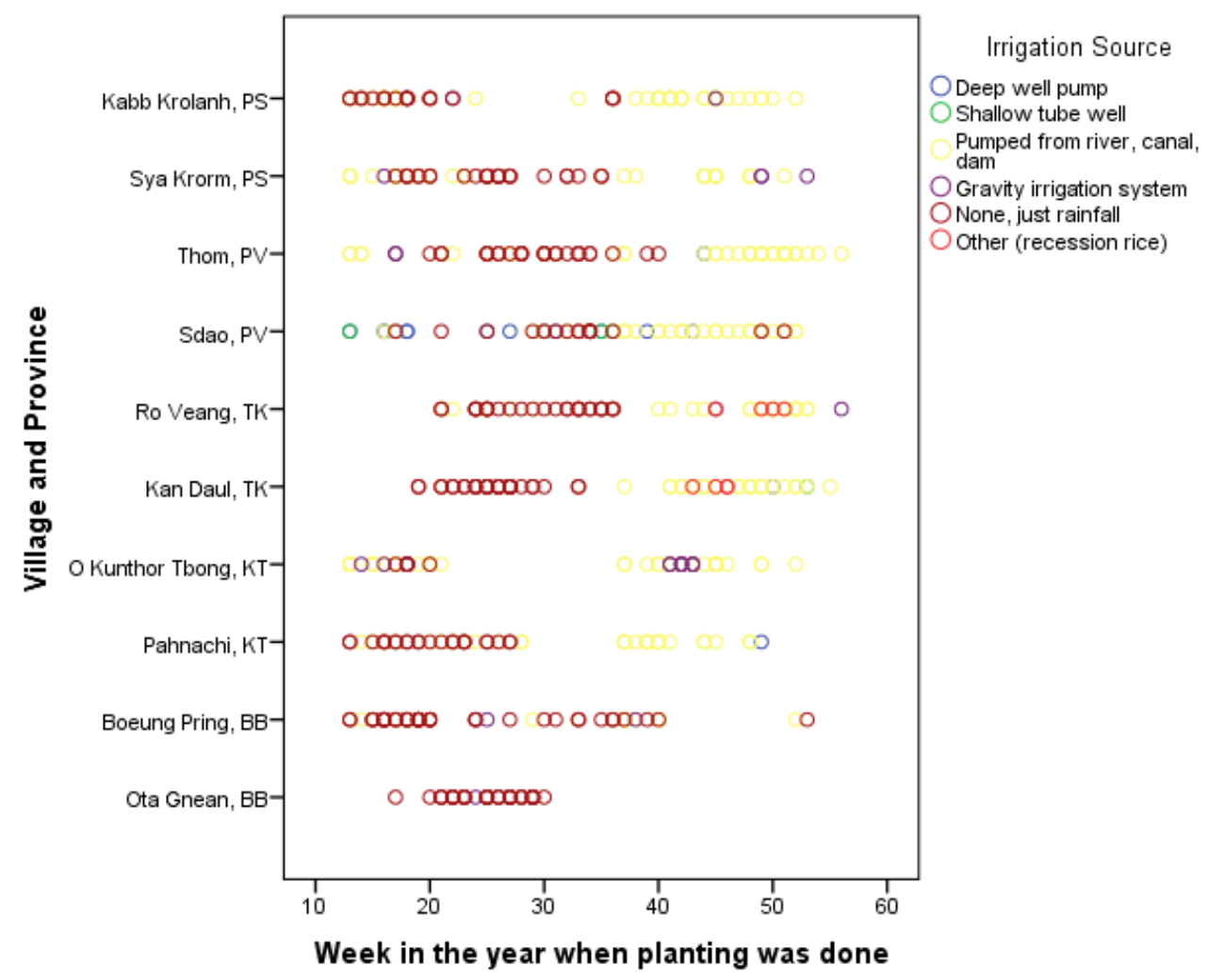

Figure 4. Incidence of crop establishment in each village across weeks in a year, by irrigation

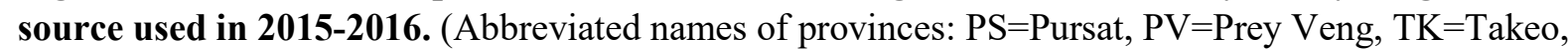
$\mathrm{KT}=$ Kampong Thom, BB=Battambang)

Farmers applied organic and chemical fertilizer between 3-5 times in one cropping season (Table 4). For all provinces, the farmers applied an average of $98.1 \mathrm{~kg} \mathrm{ha}^{-1} \mathrm{~N}( \pm 1.2 \mathrm{SE})$ in the dry season, and $84.5 \mathrm{~kg} \mathrm{ha}^{-1}( \pm 1.2 \mathrm{SE})$ in the wet season (details per province in Table 4$)$. In Battambang, the farmers applied amounts lower than the recommended rates, but in all other provinces the farmers applied higher $\mathrm{N}$ compared to recommended rates (Table 4). The total quantity of fertilizers included in the number of applications in Table 4 covered a wide range of commercial organic fertilizers. Some farmers also mentioned manure, liquid foliar, and hormone fertilizers, but these were not included in the analysis since many farmers could not remember the amount they applied. 
Table 4. Mean number of fertilizer applications, with total nitrogen rates in $\mathrm{kg} \mathrm{ha}^{-1}$ (S.E. mean) for dry and wet seasons 2015-16, including the common soil type and recommended fertilizer rates for each type

\begin{tabular}{|c|c|c|c|c|c|c|}
\hline \multirow[t]{2}{*}{ Season } & \multirow[t]{2}{*}{ Province } & \multirow[t]{2}{*}{$\begin{array}{c}\text { No. of } \\
\text { applications }\end{array}$} & \multirow[t]{2}{*}{$\begin{array}{l}\text { Total N* } \\
\left(\mathrm{kg} \mathrm{ha}^{-1}\right)\end{array}$} & \multirow[t]{2}{*}{$\begin{array}{c}\text { Common soil } \\
\text { type** }\end{array}$} & \multicolumn{2}{|c|}{$\begin{array}{l}\text { Recommended rate } \\
\left(\mathbf{N}-\mathrm{P}-\mathrm{K} \mathrm{kg} \mathrm{ha}^{-1}\right)\end{array}$} \\
\hline & & & & & $\begin{array}{l}\text { Blair and } \\
\text { Blair (2014) }\end{array}$ & CARDI \\
\hline \multirow{7}{*}{ Dry } & Battambang & $4(0.09)$ & $82.1(3.5)$ & Toul Samrong & 86-30-10 & 83-35-0 \\
\hline & Kampong Thom & $4(0.07)$ & $92.2(2.4)$ & Prateah Lang & $67-24-16$ & 50-23-30 \\
\hline & & & & Toul & 86-30-10 & $83-35-0$ \\
\hline & Takeo & $3(0.07)$ & $110.8(3.1)$ & $\begin{array}{l}\text { Samrong }^{1}, \\
\text { Prateah Lang }\end{array}$ & $67-24-16$ & 50-23-30 \\
\hline & Prey Veng & $5(0.06)$ & $105.8(1.7)$ & Prateah Lang & $67-24-16$ & 50-23-30 \\
\hline & & & & Prateah Lang, & $67-24-16$ & 50-23-30 \\
\hline & Pursat & $4(0.07)$ & $95.2(2.6)$ & Bakan $^{3}$ & 73-64-20 & 55-23-0 \\
\hline \multirow{8}{*}{ Wet } & Battambang & $3(0.09)$ & $64.3(1.9)$ & Toul Samrong & 86-30-10 & 83-35-0 \\
\hline & Kampong Thom & $3(0.07)$ & $81.8(3.0)$ & Prateah Lang & $67-24-16$ & 50-23-30 \\
\hline & & & & Toul & 86-30-10 & 83-35-0 \\
\hline & & & & Samrong $^{1}$ & $67-24-16$ & 50-23-30 \\
\hline & Takeo & $3(0.05)$ & $99.7(3.1)$ & Prateah Lang ${ }^{2}$ & & \\
\hline & Prey Veng & $4(0.07)$ & $97.4(1.8)$ & Prateah Lang & $67-24-16$ & 50-23-30 \\
\hline & & & & Prateah Lang, & $67-24-16$ & 50-23-30 \\
\hline & Pursat & $3(0.05)$ & $77.0(2.5)$ & Bakan $^{3}$ & 73-64-20 & 55-23-0 \\
\hline
\end{tabular}

\subsection{Effect of agronomic practices on pesticide use}

\subsubsection{Effect on herbicide application}

MLR identified the agronomic variables that were likely predictors of pesticide misuse relative to base outcome (SRP recommended practice); and these were area of cultivated plots in the wet season, as well as number of parcels and use of gravity irrigation in the dry season (Table 5, p values $<0.05$ ). More frequent herbicide applications were also correlated with larger cultivated areas in the wet season. These farmers were more likely to have more herbicide applications in the dry season if they cultivated fewer parcels and used gravity irrigation. Comparing between SRP practice and organic or zero herbicide applications, the significant predictors were crop establishment method, seed rate, size of landholding cultivated by the farmer, and the total number of fertilizer applications (Table 5, p values $<0.05)$. Crop establishment had a negative coefficient which means higher herbicide application (misuse) is associated with DSR. A lower seed rate is however associated with no herbicide application. Moreover, farmers with small landholdings and a low number of fertilizer applications also score low in herbicide applications (Table 5). 


\subsubsection{Effect on insecticide application}

The number of fertilizer applications were significant predictors of insecticide misuse in both seasons, but seed rate was also significant in the dry season (Table 5 , $p$ values $<0.05$ ). A greater number of fertilizer applications was correlated with a high number of insecticide applications. This is the same for wet and dry season. Similarly, high seed rate in the dry season correlated with high insecticide use (Table 5 , $p$ values $<0.05$ ).

Conversely, lower seed rates and lower numbers of fertilizer application, as shown by the coefficients, also correlated with no insecticide use (Table 5 , $p$ values $<0.05$ ). Seed rate however, was significant only in the wet season.

\subsubsection{Effect on fungicide application}

For fungicide misuse, only the number of fertilizer applications for the dry season was significant (Table $5, \mathrm{P}<0.05$ ). Greater numbers of fertilizer applications was associated with more frequent fungicide application.

No fungicide application, seed treatment, size of landholding, and number of fertilizer applications were associated in the wet season (Table 5 , $p$ values $<0.05$ ). This shows that when farmers cultivate smaller plots, they rarely use seed treatment, and have fewer fertilizer applications, they are more likely to also not apply fungicide. For the dry season, only smaller land size was associated with no application of fungicide (Table $5, \mathrm{p}$ value $<0.05$ ). 
Table 5. Multinomial logistic regression results on the effect of agronomic practices on no application (organic recommendations) and high application (pesticide misuse) of herbicide, insecticide and fungicide by Cambodian farmers from six provinces for wet and dry season 2015-2016.

\begin{tabular}{|c|c|c|c|c|c|c|c|c|c|c|c|c|c|c|c|c|c|c|}
\hline & \multicolumn{6}{|c|}{ Herbicide application } & \multicolumn{6}{|c|}{ Insecticide application } & \multicolumn{6}{|c|}{ Fungicide application } \\
\hline & \multicolumn{3}{|c|}{$\begin{array}{c}\text { Wet Season } \\
\text { No. of observations: } 371, \mathrm{LR} \\
\text { chi2 (12): 109.6, Prob>chi2: } \\
0.0000, \text { Log likelihood: - } 298.19\end{array}$} & \multicolumn{3}{|c|}{$\begin{array}{c}\text { Dry Season } \\
\text { No. of observations: } 336, \text { LR } \\
\text { chi2 (14): 35.2, Prob>chi2: } \\
0.0014 \text {, Log likelihood: }-275.37\end{array}$} & \multicolumn{3}{|c|}{$\begin{array}{c}\text { Wet Season } \\
\text { No. of observations: } 371, \mathrm{LR} \\
\text { chi2 (10): } 153.1, \text { Prob>chi2: } \\
0.0000, \text { Log likelihood: }-305.72\end{array}$} & \multicolumn{3}{|c|}{$\begin{array}{c}\text { Dry Season } \\
\text { No. of observations: } 336, \text { LR } \\
\text { chi2 (8): } 75.9, \text { Prob>chi2: } \\
\text { 0.0000, Log likelihood: }-309.87\end{array}$} & \multicolumn{3}{|c|}{$\begin{array}{c}\text { Wet Season } \\
\text { No. of observations: } 371, \mathrm{LR} \\
\text { chi2 (16): 64.6, Prob>chi2: } \\
0.0000, \text { Log likelihood: }-148.37\end{array}$} & \multicolumn{3}{|c|}{$\begin{array}{c}\text { Dry Season } \\
\text { No. of observations: } 336, \mathrm{LR} \\
\text { chi2 (10): } 24.7 \text {, Prob>chi2: } \\
0.0060 \text {, Log likelihood: }-215.12\end{array}$} \\
\hline & Coeff & S.E. & $P>|z|$ & Coeff & S.E. & $\mathbf{P}>|\mathbf{z}|$ & Coeff & S.E. & $P>|z|$ & Coeff & S.E. & $P>|z|$ & Coeff & S.E. & $P>|z|$ & Coeff & S.E. & $\mathbf{P}>|\mathbf{z}|$ \\
\hline \multicolumn{19}{|c|}{ Organic (zero application) } \\
\hline CE Method & -1.00 & 0.36 & 0.006 & -1.17 & 1.48 & 0.427 & -0.48 & 0.45 & 0.280 & -14.51 & 645.5 & 0.982 & - & - & - & - & - & - \\
\hline $\begin{array}{l}\text { Seed } \\
\text { treatment }\end{array}$ & -1.71 & 0.74 & 0.021 & - & - & - & - & - & - & - & - & - & 1.78 & 0.77 & 0.021 & 0.51 & 0.84 & 0.541 \\
\hline Seed rate & 0.00 & 0.00 & 0.005 & & & & -0.01 & 0.00 & 0.000 & 0.00 & 0.00 & 0.127 & 0.00 & 0.00 & 0.237 & 0.00 & 0.00 & 0.344 \\
\hline $\begin{array}{l}\text { Cultivar } \\
\text { resistance }\end{array}$ & - & - & - & 0.83 & 0.56 & 0.139 & - & - & - & - & - & - & 1.79 & 1.06 & 0.092 & 1.01 & 1.05 & 0.338 \\
\hline Total area & -0.45 & 0.13 & 0.000 & -0.20 & 0.12 & 0.102 & -0.11 & 0.06 & 0.060 & -0.11 & 0.08 & 0.150 & -0.21 & 0.07 & 0.004 & -0.10 & 0.05 & 0.048 \\
\hline $\begin{array}{l}\text { Number of } \\
\text { parcels }\end{array}$ & 0.20 & 0.12 & 0.105 & 0.13 & 0.17 & 0.448 & - & - & - & - & - & - & 0.33 & 0.19 & 0.080 & - & - & - \\
\hline $\begin{array}{l}\text { Use gravity } \\
\text { irrigation }\end{array}$ & - & - & - & -0.12 & 0.66 & 0.852 & - & - & - & - & - & - & -0.45 & 0.84 & 0.591 & - & - & - \\
\hline $\begin{array}{l}\text { No. fertilizer } \\
\text { application }\end{array}$ & -0.41 & 0.15 & 0.005 & -0.04 & 0.13 & 0.734 & -0.52 & 0.14 & 0.000 & -0.48 & 0.16 & 0.003 & -0.43 & 0.16 & 0.006 & -0.09 & 0.12 & 0.468 \\
\hline Total N & - & - & - & 0.00 & 0.00 & 0.408 & 0.00 & 0.00 & 0.203 & - & - & - & 0.00 & 0.00 & 0.778 & - & - & - \\
\hline \multicolumn{19}{|c|}{ SRP* (minimal application) } \\
\hline \multicolumn{19}{|c|}{ Pesticide misuse } \\
\hline CE Method & 15.08 & 801.34 & 0.985 & 11.31 & 649.30 & 0.986 & 0.23 & 0.73 & 0.756 & -0.44 & 948.53 & 1.000 & - & - & - & - & - & - \\
\hline $\begin{array}{l}\text { Seed } \\
\text { treatment }\end{array}$ & 0.10 & 1.13 & 0.931 & - & - & - & - & - & - & - & - & - & 15.75 & 1076.28 & 0.988 & -0.09 & 1.07 & 0.931 \\
\hline Seed rate & 0.00 & 0.00 & 0.254 & - & - & - & 0.00 & 0.00 & 0.457 & 0.00 & 0.00 & 0.018 & 0.00 & 0.00 & 0.281 & 0.00 & 0.00 & 0.217 \\
\hline $\begin{array}{l}\text { Cultivar } \\
\text { resistance }\end{array}$ & - & - & - & -0.42 & 0.68 & 0.535 & - & - & - & - & - & - & 0.63 & 1.47 & 0.668 & 0.29 & 1.47 & 0.842 \\
\hline Total area & 0.11 & 0.06 & 0.048 & 0.07 & 0.06 & 0.233 & -0.08 & 0.06 & 0.218 & 0.00 & 0.04 & 0.967 & -0.11 & 0.12 & 0.345 & -0.05 & 0.08 & 0.555 \\
\hline $\begin{array}{l}\text { Number of } \\
\text { parcels }\end{array}$ & -0.24 & 0.13 & 0.064 & -0.45 & 0.16 & 0.004 & - & - & - & - & - & - & 0.19 & 0.26 & 0.457 & - & - & - \\
\hline $\begin{array}{l}\text { Use gravity } \\
\text { irrigation }\end{array}$ & - & - & - & 1.07 & 0.38 & 0.005 & - & - & - & - & - & - & 0.58 & 1.10 & 0.597 & - & - & - \\
\hline $\begin{array}{l}\text { No. fertilizer } \\
\text { application }\end{array}$ & -0.06 & 0.12 & 0.636 & -0.17 & 0.11 & 0.119 & 0.36 & 0.12 & 0.003 & 0.47 & 0.10 & 0.000 & -0.04 & 0.22 & 0.850 & 0.34 & 0.16 & 0.033 \\
\hline Total $\mathrm{N}$ & - & - & - & 0.00 & 0.00 & 0.274 & 0.00 & 0.00 & 0.356 & - & - & - & 0.01 & 0.01 & 0.291 & - & - & - \\
\hline
\end{tabular}

*Based on recommendations for sustainable production from the Sustainable Rice Platform (SRP); see Stuart et al, in this issue for details. 


\section{Discussion}

Cambodian farmers in varied rice agro-ecosystems across five provinces were reliant on pesticides. Farmers from provinces in the Mekong Delta, especially Prey Veng, applied high amounts of pesticides. Agronomic practices that significantly relate to high pesticide application were identified, although these varied for herbicide, insecticide and fungicide application. There was also variation across wet and dry seasons.

Misuse of herbicide was associated with larger cultivated areas, which can be explained by a greater need for labor with weed management (Table 5). Herbicide misuse was also associated with water management, in particular managing fewer plots and reliance on gravity irrigation systems in the dry season. Conversely, PTR as a method of crop establishment, low seed rate, low fertilizer application and smaller cultivated area were associated with no herbicide use. However, these latter characteristics were rarely found. The agronomic practice most found combines high seed rates, direct seeding and high fertilizer applications (Figure 3 and Table 4). A reason to use a high seed rate is to suppress weed growth, and thus should reduce herbicide use. In contrast, our results show that high herbicide use and high seed rate go together. One explanation is that rice seed is notoriously contaminated with weed seeds; on average, 1072 weed seeds can be found in one $\mathrm{kg}$ of rice seed (Chhun et al. 2019). An assumed relation between high seed rates and low weed pressure is thus dependent on low seed contamination. Cleaning seed can be labor intensive as farmers do not use mechanical seed cleaners; therefore costs for seed cleaning may easily exceed the costs of herbicide application. Many studies have reported that herbicide use has increased in Southeast Asian countries, where the practice of DSR has widely replaced PTR (Kumar et al. 2017; Razmi et al. 2017; Khanh et al., 2006; Marsh et al., 2009).

Recently, Cambodian farmers rapidly shifted from PTR to DSR to address issues of rising labor scarcity and increasing wages (Chhim et al. 2015, Martin et al. 2017). DSR is however prone to higher weed infestation compared to PTR. With PTR, transplanting $\sim 30$ day-old seedlings gives rice competitive advantage over germinating weeds. Also, flooding after transplanting helps to suppress the initial flush of weeds at the early growth stages. There is thus a disadvantage in use of DSR. In addition, any lack of control over irrigation water further compounds this disadvantage. Without the capacity to control the irrigation and drainage of water, farmers are constrained with weed management. Flooding for weed control depends on the amount of available water, and the capacity to manage the water, i.e. flood and drain the rice field at the required moment. Without alternative techniques for weed control related to DSR early in the season, the practice of herbicide-based weed control is more attractive to farmers. The availability of labour, and alternative skills and techniques for weed control when using direct seeding, requires much more attention and has implications for herbicide use (Pandey and Velasco 2002, Ikeda et al. 2008).

Our analysis shows that cultivating a smaller area, and low number of fertilizer applications is a significant predictor of zero herbicide use. A small cultivated area could imply that farmers implement hand weeding, and consequently may not rely on herbicide. Furthermore, there are proven relationships between correct method, timing, and number of fertilizer applications that is beneficial to rice (e.g. Cassman et al 1998, Ahmed et al. 2016). Fewer fertilizer applications may be more efficient, allowing the rice to be more competitive than weeds and thus suppress herbicide use. That low seed rate is also associated with zero herbicide 
applications could be confounded by the many trade-offs faced by a farmer. Farmers with a small landholding and access to labor are able to do PTR and use low seed rates without herbicide application. PTR requires a lower seed rate than DSR, but farmers who use DSR often use higher seed rates for weed suppression (Kumar and Ladha 2011). This complexity in integrating different techniques, in a context of labor scarcity, underscores the need to search for smart and viable crop establishment practices that match well with reduced herbicide use.

Insecticide misuse was significantly associated with high seed rates and high number of fertilizer applications (Table 5). High seed rates and high frequency of fertilizer applications produce dense canopies which can positively influence incidence of pest injuries (Savary and Castilla 2013), and push farmers to reduce pest intensity (Spangenberg et al. 2015, Savary et al. 2011). Farmers from Prey Veng Province, in the Mekong Delta, consistently had higher seed rates, insecticide use and fertilizer applications during the wet and dry seasons (Tables 2 and 4, Figure 3).

Notably, gravity irrigation, which could be related to synchrony of cropping, as well as rates of $\mathrm{N}$ fertilizer application, were not found to be significant predictors of insecticide misuse. It was rather the higher number of fertilizer applications, which includes application of nitrogen, phosphorus and potassium that was related to insecticide use. This aligns more closely with studies by Rashid et al. (2017), wherein higher $\mathrm{N}$ and $\mathrm{P}$ fertilizer rates positively affected fitness traits of brown planthopper. That the rates of $\mathrm{N}$ fertilizer do not seem to be associated with high insecticide application in our sample could be due to two possible causes. One likely cause is that the total $\mathrm{N}$ was affected by the exclusion of organic fertilizer application (mostly manure) in the analysis. In this case the total number of fertilizer application, rather than total N, was a better measure of the practice of fertilizer application. Another could be that factors from outside the field such as influential local sellers who recommend calendar insecticide spraying may have stronger weight on the decision for insecticide application (Flor et al., in press). In addition, the cultivars planted by farmers were not found to be significant predictors of their insecticide use. When checked against recorded released varieties in Cambodia (Ouk et al. 2017), the commonly planted cultivars were susceptible to pests (e.g. brown plant hopper).

In comparison, zero insecticide application is associated with low seed rates and low fertilizer applications, which further confirms our findings on the interrelatedness of insecticide use with seed rates and fertilizer application (Table 5). Low level of fertilizer applications have been shown to decrease a rice plant's suitability and attractiveness as a habitat and food source for a number of herbivorous pests. Adult leaffolder moths (Cnapalochrocis medinalis), for example, lay fewer eggs when they feed on plants with low level fertilizer rate as larvae (Ge et al. 2013). The survival rate of leaffolder larvae is also lower on rice plants that were given lower amounts of $\mathrm{N}$ fertilizer (De Kraker et al. 2000). Consequently, when given a choice, adult leaffolder moths prefer to lay eggs on plants that express effects of high $\mathrm{N}$ fertilizer rate (De Kraker et al. 2000). Lu et al. (2004) showed a similar effect in reverse conditions. Low $\mathrm{N}$ application rate in rice reduced the presence of the brown planthopper (Nilaparvata lugens) because nymphs feeding on rice plants with low $\mathrm{N}$ had a longer development period and lower chances of survival. The adult hoppers laid fewer eggs during their lifespan. Low fertilizer rates thus appear to lower the attractiveness of rice as a host for herbivorous insects, which may result in lower pest populations and, in turn, affect farmers' decision of whether to apply an insecticide or not. 
Fungicide misuse was significantly associated with number of fertilizer applications (Table 5). This was most prominent in the dry season, when farmers also had a higher frequency of foliar fertilizer application (Table 4). Notably, almost every farmer (99\%) used DSR. Their fungicide use may be attributed to the occurrence of fungal diseases, such as leaf blast, neck blast (Chou et al., in press), brown spot and narrow brown spot (Castilla et al., in press) in direct-seeded fields. High fertilizer application may also result in dense canopies that create favorable conditions for diseases (Savary and Castilla, 2013), resulting in farmers opting to apply fungicides. A study by Savary et al. (2000) also observed practices of intensive rice monoculture and high chemical input in the Mekong Delta compared to other rice-growing sites in tropical Asia. The study furthermore observed medium fertilizer applications (mean of $129-162 \mathrm{~kg} \mathrm{ha}^{-1}$ ) associated with higher intensity of diseases such as brown spot and bacterial leaf blight.

Conversely, zero fungicide application was related to seed treatment, small size of cultivated plots and low number of fertilizer application (Table 5). Seed treatment is not widely practiced by farmers and untreated seeds are typically used in higher quantities. Farmers increase the seed rate, rather than treat the seeds, as precautionary measure against seed damage. The combination of high seed rate, high fertilizer application, and no seed treatment would favor the incidence of disease, which by the time symptoms are evident, the farmers would resort to fungicide. This shows how, when farmers cultivate a smaller area, apply seed treatment, and have fewer fertilizer applications, they are less likely to apply fungicide. Apparently, farmers consider available options for disease control, either through applying fungicides or biological control agents as seed treatment, but may not consider such methods effective. Other studies found that foliar spray of fungicide is more effective in reducing the secondary spread of brown spot and leaf blast than seed treatment (Agarwal et al. 2014). In the dry season, only smaller land size was a significant predictor for no application of fungicide (Table 5).

In sum, the clear correlations we found between particular forms of pest management and agronomic practices are underpinned by social and technical conditions that make specific practices more preferable for farmers. This makes our study relevant for future research on the one hand, and for agricultural policies and extension services on the other. Our study, informed by a theoretical framework that hypothesized a technological lock-in effect at the farm level, revealed several connections that provide a solid basis for studies that further explore specific mechanisms and their effects on pest control practices. Moreover, this framework encourages interdisciplinary projects that further look into combined effects of bio-chemical, agronomic, and socio-economic factors. Our results also suggest that agricultural policies and extension services should pay more attention to how recommended practices create interlocking mechanisms. Specific practices and preferred operations might be beneficial in isolation but result in adverse outcomes due to emerging effects in the complexity and variety of specific agro-ecologies. A clear example from our study is the connection between increased use of insecticide and direct seeding. In Cambodian conditions where labor has become scarce and expensive (Chhim et al. 2015, Martin et al. 2017), farmers would tend to adopt DSR. Observably, Cambodian farmers using DSR also tend to use high seed rates that in turn strongly relate to high insecticide use. Although it may be better for farmers to use less seeds, because seed rate and DSR can increase the incidence and spread of insect pests and disease (Ishii-Eiteman and Power 1997, Horgan 2017), it is not easy for farmers to do so. More so because farmers seem to use high seed rates as a form of weed 
control. Herein is an example of a configuration of the social and technical aspects where labor conditions, DSR and high seed rates are linked with pesticide use.

Finally, our results show the importance of continuous efforts for developing and adjusting alternative technologies such as Integrated Pest Management (IPM). IPM has been introduced in Cambodia for the past two decades with proven benefits (Ngin et al. 2017). Rice IPM covers techniques and tools to prevent damaging levels of pests and minimize the need for curative tactics such as pesticides (Heinrichs et al. 2017). For insect pests, this can include tactics such as synchronous planting, use of light traps, biological control agents, or selective use of insecticide. Farmers may opt for insecticides, instead of using it only as the last resort; not because they do not know or like IPM, but rather they are also making trade-offs that connect their choice of pest management with various agronomic practices.

\section{Conclusion}

We tested whether field level agronomic practices of Cambodian farmers were related to their pesticide-based pest management, and the the possible role of these practices in the technological lock-in of pesticides. Combinations of agronomic practices were significantly associated with herbicide, insecticide and fungicide application including seed rate, crop establishment method, water management in gravity irrigation systems, size of landholding cultivated, number of fertilizer applications, and seed treatment. These field-level practices, associated with the decisions of farmers on pest management, are therefore important factors to consider in easing out of the pesticide lock-in. Notably, there are limits where decisions may not be only influenced by agronomic factors but rather by external factors, such as economic tradeoffs, available information, and habits. In conceptual terms, the pathdependency to control pest through the use of pesticide not only relates to factors inherent in the production, distribution and application of pesticides, but also includes a wider set of agronomic factors in rice cultivation.

These findings have implications for alternative technology packages such as Integrated Pest Management. To counter pesticide lock-in and shift to more sustainable systems, there are adjustments that need to be made on field-level agronomic practices, not only in the level of innovation systems, such as changes in policies, industry for alternative technologies and extension interventions.

\section{Acknowledgements}

This study was implemented under the Ecologically based Participatory Integrated Pest Management for Rice in Cambodia (EPIC) Project of the International Rice Research Institute (IRRI), funded by the United States Agency for International Development (USAID), Feed the Future IPM Innovation Laboratory. We also acknowledge funding support from the Postdoc Talent Program of the Wageningen Graduate School, through the Wageningen School of Social Sciences (WASS). We thank Frazen Tolentino_Zondervan and Alaine Gulles for their advice on the analysis, as well as Grant Singleton, Sarah Beebout and David Johnson for insightful comments on the paper. Lastly, we are grateful to the reviewers for their help in improving the manuscript. 


\section{References}

Ahmed, S., Humphreys, E., Salim, M., Chauhan, B.S., 2016. Growth, yield and nitrogen use efficiency of dry-seeded rice as influenced by nitrogen and seed rates in Bangladesh. Field Crops Res. 186, 18-31.

Ahmed, S., Salim, M., Chauhan, B.S., 2014. Effect of weed management and seed rate on crop growth under direct dry seeded rice systems in Bangladesh. PLoS One 9, e101919.

Alam, S.N., Cohen, M.B., 1998. Durability of brown planthopper, Nilaparvata lugens, resistance in rice variety IR64 in greenhouse selection studies. Exp Appl Entomol 89, 71-78.

Albuquerque, G.S., 1993. Planting time as a tactic to manage the small rice stink bug, Oebalus poecilus (Hemiptera: Pentatomidae), in Rio Grande do Sul, Brazil. Crop Prot 12, 627-630.

Arthur, W.B., 1989. Technologies, increasing returns and lock-in by historical events. Econ J 99, 116-131.

Blair, G., Blair, N., 2014. Nutrient status of Cambodian soils, Rationalisation of fertilizer recommendations, and the challenges ahead for Cambodian soil science. Curr Agric Res J 2, 5-13. DOI: 10.12944/CARJ.2.1.02.

Cabunagan, R.C., Castilla, N., Coloquio, E.L., Tiongco, E.R., Truong, X.H., Fernandez, J., Du, M.J., Zaragosa, B., Hozak, R.R., Savary, S., Azzam, O., 2001. Synchrony of planting and proportions of susceptible varieties affect rice tungro disease epidemics in the Philippines. Crop Prot 20, 499-510.

Cassman, K.G., Peng, S., Olk, D.C., Ladha, J.K., Reichardt, W., Dobermann, A., Singh, U., 1998. Opportunities for increased nitrogen-use efficiency from improved resource management in irrigated rice systems. Field Crops Res. 56, 7-39.

Castilla, N.P, Savary, S., 2003. Interaction of nutrients with rice diseases and insect pests: Existing knowledge and research directions, in: Mew, T.W, Brar, D.S., Dawe D., Hardy, B.(Eds.), Rice Science: Innovations and Impact for Livelihood, International Rice Research Institute, Manila, Philippines, Chinese Academy of Engineering and Chinese Academy of Agricultural Sciences, Beijing, China, pp. 487-505.

Chan, Y.H., 2005. Biostatistics 305. Multinomial logistic regression. Singapore Med J 46, 259-269.

Chauhan, B.S., 2012. Weed ecology and weed management strategies for dry seeded rice in Asia. Weed Technol 26, 1-13.

Chauhan, B.S., Singh, V.P., Kumar, A., Johnson, D.E., 2011. Relations of rice seeding rates to crop and weed growth in aerobic rice. Field Crops Res 121, 105-115.

Chhim, C., Buth, B., Ear, S., 2015. Effect of Labour Movement on Agricultural Mechanisation in Cambodia. CDRI Working Paper Series. Cambodia Development Research Institute, Phnom Penh .

Cohen, M.B., Alam, S.N., Medina, E.B., Bernal, C.C., 1997. Brown planthopper, Nilaparvata lugens, resistance on rice cultivar IR64: Mechanisms and role in successful N. lugens management in Central Luzon, Philippines. Exp Appl Entomol 85, 221-229.

Cowan, R., Gunby, P., 1996. Sprayed to death: path dependence, lock-in and pest control strategies. Econ J 106, 521-542. 
De Kraker, J., Rabbinge, R., van Huis, A., van Lenteren, J.C., Heong, K.L., 2000. Impact of nitrogenous-fertilization on the population dynamics and natural control of rice leaffolders (Lep.: Pyralidae). Int J Pest Manage 46, 225-235.

Flor R.J., Chhay K., Sorn V., Maat H., Hadi B.A.R. 2018. The technological trajectory of Integrated Pest Management for rice in Cambodia. Sustainability 10: 1-14. DOI: $10.3390 /$ su10061732

Flor, R., Maat, H., Hadi, B., Then, R., Kraus, E., Chhay, K., 2019, forthcoming. Village level dynamics affecting pest management in Cambodia: Stakeholder interactions that contribute to a pesticide lock-in. (Accepted pending minor revisions in Crop Protection).

Foxon, T.J., 2013. Technological lock-in. Encyclopedia of Energy, Natural Resource, and Environmental Economics 1, 123-127.

Ge, L.Q., Wan, D.J., Xu, J., Jiang, L.B., Wu, J.C., 2013. Effects of nitrogen fertilizer and magnesium manipulation on the Cnaphalocrocis medinalis (Lepidoptera: Pyralidae). J. Econ. Entomol. 106, 196-205.

Heinrichs, E.A., Nwilene F.E., Stout, M., Hadi, B.A.R., Freitas, T., 2017. Integrated Pest Management (IPM) of Rice. Burleigh Dodds Science Publishing Limited, Cambridge.

Heong, K.L., Escalada, M., 1999. Quantifying rice farmers' pest management decisions: beliefs and subjective norms in stem borer control. Crop Prot 18, 315-322.

Holt, J., Chancellor, T.C.B., 1997. A model of plant virus disease epidemics in asynchronously-planted cropping systems. Plant Pathol 46, 490-501.

Horgan, F. 2017. Integrated pest management for sustainable rice cultivation: a review. in: Sasaki, T. (Eds.), Achieving Sustainable Cultivation of Rice. Burleigh Dodds Science Publishing Limited. Cambridge, UK, pp. 309-343.

Htwe, N.M., Singleton, G.R., Nelson, A., 2013. Can rodent outbreaks be driven by major climatic events? Evidence from cyclone Nargis in the Ayayawaddy Delta, Myanmar. Pest Manage Sci 69, 378-385.

Huber, D., Romheld, D., Weinman, M., 2012. Relationship between nutrition, plant diseases and pests. in: Marschner's Mineral Nutrition of Higher Plants, third ed. Elsevier/Academic Press, Amsterdam, Netherlands, pp. 283-289. https://doi.org/10.1016/C2009-0-63043-9.

Ikeda, H., Kamoshita, A., Yamagishi, J., Ouk, M., Lor, B., 2008. Assessment of management of direct seeded rice production under different water conditions in Cambodia. Paddy Water Environ 6, 91-103.

IRRI, PLAN, CARDI, 2015. SROV PHAL for rainfed lowland rice in Cambodia: Kampong Cham and Siem Reap Province. In: International Rice Research Institute, PLAN, and Cambodian Agricultural Research and Development Institute. IRRI, Los Banos, Philippines. (I have problems with the citation for this manual)

Joly, P., Lemarie, S., 2002. The technological trajectories of the agrochemical industry: change and continuity. Sci Pub Pol 29, 259-266.

Khanh, T.D., Xuan, T.D., Elzaawely, A., Tawata, S., 2006. Current status of biological control of paddy weeds in Vietnam. Weed Biol Manage 6, 1-9.

Kiraly, Z., 1964. Effect of nitrogen fertilization on phenol metabolism and stem rust susceptibility of wheat. J Phytopathol 51, 252-261. 
Koyama J. 1955. Studies on the paddy borer (Schoenobius incertulas). Wakayama-Ken. Agric. Res. Stn. 53,169-174.

Kumar, V., Ladha, J.K. 2011. Direct seeding of rice: Recent developments and future research needs. Adv Agron 111, 297-413.

Kumar, V., Opena, J., Valencia, K., Thi, H.L.,Son, N.H., Donayre, D.K., Janiya, J., Johnson, D.E., 2017. Rice weed management in Southeast Asia. Asian-Pacific Weed Science Society, in; Rao, A.N., Matsumoto, S. (Eds.), Weed Management in Rice in the Asian-Pacific Region. The Weed Science Society of Japan, and Indian Society of Weed Science, pp. 282- 307.

Loevinsohn, M.E., Bandong, J.P, dd Alviola A.A.. 1993. Asynchrony of cultivation among Philippine rice farming: causes and prospects for change. Agric Syst 41, 419-439.

Lu, Z., Heong, K.L., 2009. Effects of nitrogen-enriched rice plants on ecological fitness of planthoppers. in: K.L. Heong, B. Hardy (Eds.), Planthoppers: New Threats to the Sustainability of Intensive Rice Production Systems in Asia, International Rice Research Institute, Los Baños, Philippines, pp 247-256.

Lu, Z., Heong, K.L., Yu, X.P., Hu, C., 2004. Effects of plant nitrogen on ecological fitness of the brown planthopper, Nilaparvata lugens in rice. J Asia Pac Entomol 7, 97-104.

Madhu, B., Ashok, N.C., Balasubramanian, S., 2014. A multinomial logistic regression analysis to study the influence of residence and socio-economic status on breast cancer incidences in Southern Karnataka. IJMSI 2, 1-8.

Marsh, S., Casimero, D., Llewellyn, R., Pannell, D., 2009. Final report: Herbicide use strategies and weed management options in Filipino and Australian cropping. Australian Center for International Agricultural Research, Canberra, Australia.

Martin, R.J., Van Ogtrop, F., Henson, Y., Broeum, K., Rien, R., Srean, P., Tan, D.K.Y., 2017. A survey of weed seed contamination of rice paddy in Cambodia. Weed Res 57, 333-341.

Matsukawa, M., Ito, K., Kawakita, K., Tanaka, T., 2016. Current status of pesticide use among rice farmers in Cambodia. Appl Entomol Zool 51, 571-579.

Matsuyama, N., 1975. The effect of ample nitrogen fertilizer on cell-wall materials and its significance to rice blast disease. Ann Phytopathol Soc Jpn 41, 56-62.

Matsuyama, N., Dimond, A.E., 1973. Effect of nitrogenous fertilizer on biochemical processes that could affect lesion size of rice blast. Phytopathol 63, 1202-1203.

Mumford, J.D., Norton, G.A., 1984. Economics of decision making in pest management. Annu Rev Entomol 29, 157-174.

Ngin, C., Seng, S., Tanaka, T., Yamauchi, A., Cedicol, E., Kawakita, K., Chiba, S. 2017. Rice productivity improvement in Cambodia through the application of technical recommendation in a farmer field school. Int J Agr Sustain 15, 54-69. DOI: 10.1080/14735903.2016.1174811

NIS, 2015. Census of Agriculture in Cambodia 2013. Ministry of Planning and Ministry of Agriculture Forestry and Fisheries, Phnom Penh, p. 304.

O’Donovan, J.T., Harker, K.N., Clayton, G.W., Newman, J.C., Robinson, D., Hall, L.M., 2001. Barley seeding rate influences the effects of variable herbicides rates on wild oat. Weed Sci 49, 746-754.

O’Donovan, J.T., Newman, J.C., Harker, K.N., Blackshaw, R.E., McAndrew, D.W., 1999. Effect of barley plant density on wild oat interference, shoot biomass and seed yield under zero tillage. Can J Plant Sci 79, 655-662. 
Ouk, M., Sakhan, S., Men, S., Thun, V., Seang, L., Chaudhary R.C., Javier, E., Hun, Y., Pith, K., Khun, L., Sidhu, G.S., Sin, S., Say, P., Ung, S., Preap, V., Kong, K., Orn, C., Ouk, S., Nou, K., Zhao, D., Fitzgerald, M., Sen, S., Ouch, S., Yon, S., Vat, S., Mat, L., Leng, L., Then, R., Sok, S., Net, S., Sim, T., 2017. Description of crop varieties released by Cambodian Agricultural Research and Development Institute (1990-2017). Cambodian Agricultural Research and Development Institute, Phnom Penh.

Pandey, S., Velasco, L., 2002. Economics of direct seeding in Asia: patterns of adoption and research priorities, in: Pandey, S., Mortimer, M., Wade, L., Tuong, T.P., Lopez, K., Hardy, B. (Eds.), International Workshop on Direct Seeding in Asian Rice Systems: Strategic Research Issues and Opportunities, . 25-28 January 2000, Bangkok, Thailand. International Rice Research Institute, Bangkok, Thailand, pp. 3-14.

Parveen, S., Nakagoshi, N., 2001. An analysis of pesticide use for rice pest management in Banglandesh. J Int Dev Coop 8, 107-126.

Perkins, R., 2003. Technological "lock-In". Internet Encycopedia for Ecological Economics. International Society for Ecological Economics. http://isecoeco.org/pdf/techlkin.pdf, last accessed on May 2018

Rao, A.N., Brainard, D.C., Kumar, V. Ladha, J.K., Johnson, D., 2017. Preventive weed management in direct-seeded rice: Targeting the weed seed bank. Adv Agron 144, 45-142.

Rao, A.N., Johnson, D.E., Sivaprasad, B., Ladha, J.K., Mortimer, A.M., 2007. Weed management in direct-seeded rice. Adv Agron 93, 153-255.

Reddy, A.P.K., Katyal, J.C., Rouse, D.I., MacKenzie, D.R., 1979. Relationship between nitrogen fertilization, bacterial leaf blight severity, and yield of rice. Phytopathol 69, 970-973.

Ruzmi, R., Ahmad-Hamdani, M.S., Bakar, B.B., 2017. Prevalence of herbicide-resistant weed species in Malaysian rice fields: A review. Weed Biol Manage 17, 3-16.

Savary, S., Castilla, N., Elazegui, F.A., Teng, P., 2005. Multiple effects of two drivers of agricultural change, labour shortage and water scarcity, on rice pest profiles in tropical Asia. Field Crops Res 91, 263-271.

Savary, S., Nelson, A., Sparks, A.H., Willocquet, L., Duveiller, E., Mahuku, G., Forbes, G., Garrett, K., Hodson, D., Padgham, J., Pande, S., Sharma, S., Yuen, J., Djurle A., 2011. International agricultural research tackling the effects of global and climate changes on plant diseases in the developing world. Plant Dis 95, 1204-1216.

Savary, S., Willocquet L., Elazegui, F., Teng, P., Du, P.H., Zhu, D., Tang, Q., Huang, S., Lin, X., Sing, H.M., Srivastava, R.K., 2000. Rice pest constraints in tropical Asia: Characterization of injury profiles in relation to production situations. Plant Dis 84, 341-356.

Spangenberg, J.H., Douguet, J.M., Settele, J., Heong, K.L., 2015. Escaping the lock-in of continuous insecticide spraying in rice: Developing an integrated ecological and sociopolitical DPSIR analysis. Ecol Model 295, 188-195.

SRP. 2015. Standard on sustainable rice cultivation. Sustainable Rice Platform. Bangkok. Accessed at: http://www.sustainablerice.org

Stout, M., Riggio, M.R., Zou, L., Roberts, R., 2002. Flooding influences ovipositional and feeding behavior of the rice water weevil (Coleoptera: Curculionidae). J Econ Entomol 95, 715-721.

Stuart, A., Devkota, K., Sato, T., Pame, A.R., Balingbing, C., Nguyen, M.P., Nguyen, K., Pham, M.H., Tran, H., Beebout, S., Singleton, G.R. 2018. On-farm assessment of different 
677 rice crop management practices in the Mekong Delta, Vietnam, using sustainability

678 performance indicators. Field Crops Res 229, 103-114. DOI: 10.1016/j.fcr.2018.10.001

679 Tabanick, B.G., Fidell, L.S., Osterlind, S.J., 2001. Using multivariate statistics. Allyn and 680 Bacon, Boston.

681 Thien, H.X., Du, P.V., Tan, P.S., Singh, U.S., Cruz, P.C.S., Dobermann, A., Hill, J.E., 1999.

682 Nutrient and pest interaction in terms of prevention from rice yield declining symptom in 683 Mekong Delta. OMONRICE 7, 1-11.

684 Vaithilingam, C., Baskaran, P., 1985. Induced resistance to insect pests in rice with enhanced 685 potassium application, in: Role of potassium in crop resistance to insect pests. Potash 686 Research Institute, Haryana, India, pp. 43-51.

687 Van Loqueren, G., Baret, P., 2009. How agricultural research systems shape a technological 688 regime that develops genetic engineering but locks out agroecological innovations. Res Policy $68938,971-983$.

690 Vergara B.S,, Lilis R,,Tanaka A. 1964. Relationship between length of growing period and 691 yield of rice plants under a limited nitrogen supply. Soil Sci Plant Nutr10, 15-21.

692 Wagner, C.H., Cox, M., Bazo Robles, J.L., 2006. Pesticide lock-in in small scale Peruvian 693 agriculture. Ecol Econ 129, 72-81. 